\title{
Nodular Amyloidoma and Primary Pulmonary Lymphoma with Amyloid Production: A Differential Diagnostic Problem
}

\author{
Sanja Dacic, M.D., Ph.D., Thomas V. Colby, M.D., Samuel A. Yousem, M.D. \\ Departments of Pathology, University of Pittsburgh Medical Center and Presbyterian University Hospital, \\ Pittsburgh, Pennsylvania (SD, SAY), and Mayo Clinic Scottsdale, Scottsdale, Arizona (TVC)
}

Nodular amyloidomas (NA) of the lung are nonneoplastic inflammatory nodules containing eosinophilic amyloid deposits and a lymphoplasmacytic infiltrate. In some instances, the extensive amyloid deposits may obscure an underlying lymphoproliferative disorder. The histologic and immunohistologic features that discriminate these two differential diagnostic possibilities were studied in this series of six cases of NA and five cases of primary low-grade malignant lymphomas of lung with secondary amyloid deposits (ML). Two of lymphoma cases showed histopathologic and immunophenotypic features of B-cell chronic lymphocytic leukemia/small lymphocytic lymphoma (B-cell CLL/SLL), and three cases were low-grade B-cell lymphoma derived from mucosa associated lymphoid tissue (MALT lymphoma). Key discriminating morphologic features between NA and ML included lymphatic tracking of the cellular infiltrate $(3 / 5 \mathrm{ML} ; 1 / 6$ NA), pleural infiltration (3/5 ML; 0/6 NA), sheet-like masses of plasma cells (5/5 ML; 0/6 NA) and reactive follicles (4/5 ML; 1/6 NA). Lesional circumscription, vascular and bronchial destruction, lymphoepithelial lesions, and granulomas were not helpful discriminators. Immunohistochemical features indicating a dominant $\mathrm{CD20+,}$ CD79a+ B-cell population (5/5 ML; 0/6 NA), light chain restriction (4/5 $\mathrm{ML}$; 0/6 NA), and aberrant antigen expression of CD20/CD43 (2/5 ML; 0/6 NA) were helpful. Amyloid tumors with a reactive lymphoplasmacytic infiltrate can be separated from low-grade malignant lymphomas utilizing both histologic and immunohistochemical features.

Copyright () 2000 by The United States and Canadian Academy of Pathology, Inc.

VOL. 13, NO. 9, P. 934, 2000 Printed in the U.S.A.

Date of acceptance: April 6, 2000.

Address reprint requests to: Sanja Dacic, M.D., Ph.D., Department of Pathology, Room A610, University of Pittsburgh Medical Center; Presbyterian University Hospital, 200 Lothrop St., Pittsburgh, PA 15213; e-mail: dacics@msx.upmc.edu; fax: 412-647-3399.
KEY WORDS: Amyloid, Amyloidoma, Lung, Lymphoma.

Mod Pathol 2000;13(9):934-940

Three forms of pulmonary amyloidosis have been recognized in the literature: diffuse alveolar septal, nodular, and tracheobronchial (1-4). The most common form is nodular amyloidosis, a rare condition with a good prognosis that usually presents in older individuals as asymptomatic nodules identified on routine chest x-rays. Histologically, nodular amyloidomas are well-circumscribed consolidated masses of dense, amorphous eosinophilic amyloid, often associated with a modest inflammatory cell infiltrate, consisting of clusters of plasma cells and lymphocytes with an occasional granulomatous reaction to the amyloid. Calcification and metaplastic ossification are common. The cause of these nodular amyloidomas is unclear although it has been hypothesized that they represent a reaction to chronic inflammatory conditions affecting the lung, such as connective tissue disorders, tuberculosis, or HIV infection (5-7). Amyloidomas are also associated with systemic lymphoproliferative disorders and plasma cell dyscrasias, primarily multiple myeloma, and lymphoplasmacytic lymphoma $(8,9)$. These individuals usually have amyloid deposits as a result of serum lambda light chains depositing within the pulmonary parenchyma with kappa light chains occurring less frequently in contrast to most B-cell malignancies (10, 11). Still other patients have primary pulmonary lymphomas with amyloid production, and it is in this group that morphologic confusion with nodular amyloidoma occurs. To better highlight the characteristics that distinguish nodular amyloid from primary pulmonary lymphomas with amyloid deposits, we undertook a study of the histologic and immunohistochemical features that allow discrimination of these three differential diagnostic possibilities. 


\section{MATERIALS AND METHODS}

The surgical pathology files of the University of Pittsburgh Medical Center and the consultation files of one of the authors (SAY) were reviewed for all cases of amyloid involvement of the lung. Twelve cases with nodular amyloidosis were identified; however, only six cases were diagnosed by open lung biopsy and had sufficient material available for subsequent studies. Three cases of primary pulmonary lymphoma with amyloid deposits were identified and were supplemented by two cases obtained from Mayo Clinic, Scottsdale, Arizona. Clinical information was obtained from accompanying surgical pathology reports and the patients' medical records. In addition, follow-up questionnaires were completed by referring pathologists and primary care physicians. No patient with nodular amyloidoma developed a lymphoproliferative disorder, and all cases of pulmonary lymphoma presented with lung involvement exclusively. All patients were alive and well at last contact with their physicians.

For conventional light microscopic examination, formalin-fixed, paraffin-embedded $4-\mu \mathrm{m}$ tissue sections were stained with hematoxylin and eosin. Congo red stains were performed and a diagnosis of amyloid was confirmed in all cases by apple green birefringence under polarized light examination. The following histologic features were evaluated: circumscription of lesion, lymphatic tracking, and the presence of pleural, blood vessel, and bronchial invasion by the mononuclear cells, lymphoepithelial lesions, secondary follicles, granulomas/giant cells, plasma cell infiltrates as small aggregates (less than 20 cells) or broad sheets, cytologic features of the lymphocytes, and Dutcher bodies.

Immunophenotyping was performed with the commercially available antibodies described in Ta- ble 1 using an automated immunostainer (Ventana Medical Systems, Inc.; Tucson, AZ) and applying previously described methods (12). Heat-induced antigen retrieval was performed using microwave technology. Appropriate positive and negative controls were performed.

Lymphomas were classified according to morphologic and immunophenotypic features described in REAL classification (13). B-cell chronic lymphocytic leukemia/small lymphocytic lymphomas (CLL/SLL) were composed predominantly of small round lymphocytes with clumped chromatin with occasional larger lymphoid cells usually clustered as pale proliferation centers. Lymphoma cells of B-cell CLL/SLL showed weak surface immunoglobulin positivity (usually IgM) and B-cell associated antigens (CD19, CD20, CD79a), CD5+, CD10-, CD23+, and CD43+ (13).

Low-grade B-cell lymphoma of MALT type in REAL classification is recognized as an extranodal counterpart of marginal zone B-cell lymphoma (13). Histologically, these lymphomas are characterized by cellular heterogeneity, including marginal zone (centrocyte-like) cells, small lymphocytes, monocytoid lymphocytes, and plasma cells. Reactive follicles are often present. Lymphoma cells express surface immunoglobulin (IgM more often than IgG), B-cell associated antigens (CD19, CD20, CD79a), and they are CD5-, CD10-, CD23-, CD43 \pm (13).

\section{RESULTS}

Table 2 summarizes the clinicopathologic features of the 11 patients in this study. Of the six patients with nodular amyloidoma, three were women and three were men, with ages ranging from 25 to 65 years (mean, 55 years). Chest radio-

TABLE 1. Antibodies Used in Study of Pulmonary Amyloidomas and Lymphomas with Amyloid

\begin{tabular}{lllll}
\hline \multicolumn{1}{c}{ Antigen } & \multicolumn{1}{c}{ Source } & Dilution & \multicolumn{1}{c}{ Antigen Retrieval Method } \\
\hline CD3 & Dako, Carpinteria, CA & $1: 400$ & Microwave in citrate buffer \\
CD5 & Novocastra, Burlingame, CA & $1: 80$ & Microwave in Tris-EDTA & T cell \\
CD10 & Novocastra & $1: 15$ & Microwave in citrate & P cell \\
CD20 & Dako & $1: 60$ & Microwave in citrate & B cell \\
CD21 & Dako & $1: 30$ & Ventana protease 1 for 12 min ${ }^{b}$ & Mantle and marginal zone B cell, FDC $_{\text {CD23 }}$ \\
CD43 & The Binding Site, San Diego, CA & $1: 200$ & None & Mantle and marginal zone B cell, FDC \\
& Dako & $1: 400$ & Microwave in citrate + & T cells, some B cells, myeloid \\
CD79a & & & Ventana protease & B cells \\
Kappa light chain & Neomarkers, Fremont, CA & $1: 50$ & Microwave in citrate & B-cell subset \\
Lambda light chain & $1: 100$ & Microwave in Tris-EDTA & B-cell subset \\
IgA & Neomarkers & $1: 100$ & Microwave in Tris-EDTA & B-cell subset \\
IgD & Dako & $1: 600$ & Microwave in citrate & B-cell subset \\
IgG & Dako & $1: 300$ & Microwave in citrate & B-cell subset \\
IgM & Dako & $1: 2000$ & Microwave in citrate & B-cell subset \\
Cyclin D1 & Dako & $1: 4000$ & Microwave in citrate & Mantle cell lymphoma \\
\hline
\end{tabular}

FDC, follicular dendritic cells.

a $10 \mathrm{mM}$ citrate, $\mathrm{pH} 6.0$ for $15 \mathrm{~min}$.

${ }^{b}$ Venta proprietary formula. 
TABLE 2. Clinicopathological Features of Nodular Amyloidomas and Primary Pulmonary Lymphomas with Amyloid Deposits

\begin{tabular}{|c|c|c|c|c|c|c|c|c|c|c|c|c|c|c|c|}
\hline \multirow{2}{*}{ Cases } & \multirow{2}{*}{ Diagnosis } & \multirow{2}{*}{$\begin{array}{l}\text { Age } \\
\text { (yrs) }\end{array}$} & \multirow{2}{*}{ Sex } & \multirow{2}{*}{ Chest X-Ray } & \multirow{2}{*}{$\begin{array}{l}\text { Lymphatic } \\
\text { Tracking }\end{array}$} & \multicolumn{3}{|c|}{ Invasion } & \multirow{2}{*}{$\begin{array}{c}\text { Plasma } \\
\text { Cell } \\
\text { Sheets }\end{array}$} & \multicolumn{3}{|c|}{ Cytology } & \multirow{2}{*}{ LEL } & \multirow{2}{*}{ GC } & \multirow{2}{*}{$\begin{array}{l}\text { Gran- } \\
\text { ulomas }\end{array}$} \\
\hline & & & & & & Bronchial & Pleural & Vascular & & SL & ML & $\mathrm{PC}$ & & & \\
\hline \multicolumn{16}{|c|}{ Lymphoma } \\
\hline$\# 1$ & B-cell CLL/SLL & 75 & $\mathrm{~F}$ & Solitary nodule & + & - & + & - & + & + & - & - & - & - & - \\
\hline$\# 2$ & MALToma & 79 & $\mathrm{~F}$ & Solitary nodule & + & + & + & + & + & + & - & + & + & + & + \\
\hline$\# 3$ & MALToma & 70 & $\mathrm{~F}$ & Multiple nodules & + & + & + & + & + & + & - & + & - & + & + \\
\hline$\# 4$ & MALToma & 75 & $\mathrm{~F}$ & Multiple nodules & - & - & - & + & + & + & - & + & - & + & + \\
\hline \#5 & B-cell CLL/SLL & 70 & $\mathrm{M}$ & Multiple nodules & - & + & - & + & + & + & - & + & - & + & + \\
\hline \multicolumn{16}{|c|}{ Amyloidoma } \\
\hline$\# 6$ & $\begin{array}{l}\text { Nodular } \\
\text { amyloid }\end{array}$ & 61 & $\mathrm{M}$ & $\begin{array}{l}\text { Diffuse pleural } \\
\text { thickening }\end{array}$ & - & - & - & - & - & + & - & - & - & - & + \\
\hline$\# 7$ & $\begin{array}{l}\text { Nodular } \\
\text { amyloid }\end{array}$ & 65 & $\mathrm{M}$ & Multiple nodules & - & - & - & - & - & + & - & + & - & - & + \\
\hline \#8 & $\begin{array}{l}\text { Nodular } \\
\text { amyloid }\end{array}$ & 25 & $\mathrm{~F}$ & Solitary nodule & - & + & - & - & - & + & - & + & - & + & - \\
\hline$\# 9$ & $\begin{array}{l}\text { Nodular } \\
\text { amyloid }\end{array}$ & 55 & $\mathrm{~F}$ & $\begin{array}{l}\text { Multifocal } \\
\text { pneumonic } \\
\text { infiltrates }\end{array}$ & - & - & - & - & - & + & - & + & - & - & + \\
\hline$\# 10$ & $\begin{array}{l}\text { Nodular } \\
\text { amyloid }\end{array}$ & 62 & $\mathrm{~F}$ & Multiple nodules & + & - & - & + & - & + & + & + & - & - & - \\
\hline$\# 11$ & $\begin{array}{l}\text { Nodular } \\
\text { amyloid }\end{array}$ & 60 & M & Multiple nodules & - & + & - & + & - & + & + & + & - & - & + \\
\hline
\end{tabular}

M, male; F, female; B-cell CLL/SLL, B-cell chronic lymphocytic leukemia/small lymphocytic lymphoma; MALToma, low-grade B cell lymphoma derived from mucosa associated lymphoid tissue; SL, small lymphocytes; ML, monocytoid lymphocytes; PC, plasma cells; LEL, lymphoepithelial lesion; GC, germinal centers.

graphs revealed multiple nodules in three cases, a solitary pulmonary nodule in one case, subpleural pulmonary parenchymal nodules with pleural thickening in one case, and multifocal pneumonic infiltrates in the last case. At low magnification, all nodular amyloidomas demonstrated wellcircumscribed masses of dense amorphous eosinophilic material with the histochemical and tinctorial properties of amyloid. The central mass of amyloid like material was relatively paucicellular, with a predominant mononuclear infiltrate present at the periphery of the lesion (Fig. 1). Lymphatic tracking of the mononuclear cells at the edge was seen in only one of the six cases and was characterized by dense aggregates of lymphocytes circumferentially enveloping pulmonary veins and lymphatics within the pleura, interlobular septa, and bronchovascular bundles. Amyloid deposits were seen within the walls of blood vessels and airways in $33 \%$ of cases, with such involvement associated with a mural mononuclear inflammatory cell infiltrate (Fig. 2). A granulomatous reaction was seen in four of six cases $(67 \%)$ and typically consisted of masses of giant cells surrounding amyloid deposits (Fig. 3). Reactive lymphoid follicles with germinal centers were observed in only one case $(17 \%)$. The inflammatory infiltrate consisted primarily of small lymphocytes, plasma cells, and histiocytes. Only two of the six cases showed scant medium-sized lymphoid cells with reniform nuclei, inconspicuous nucleoli, and abundant pale-staining cytoplasm, resembling monocytoid B cells. Large lymphoid cells were not seen. Plasma cells were present in $83 \%$ (five of six) of cases. However, a sheet-like distribu- tion of plasma cells was not observed (aggregates of greater than 20 cells). No Dutcher bodies, lymphoepithelial lesions, or pleural infiltration were identified.

Of the five patients with primary pulmonary lymphoma, four were female and one was male, with ages ranging from 70 to 79 years (mean, 75 years). Chest radiographs demonstrated solitary pulmonary nodules in two cases and multiple bilateral pulmonary nodules in three instances. At low magnification, the nodules were well circumscribed; however, lymphatic tracking was identified in $60 \%$ (three of five) of cases with the mononuclear infiltrate cuffing pulmonary veins and lymphatics (Fig. 4). The lymphoid infiltrate showed a more even distribution throughout the nodule than that seen in nodular amyloidomas (Fig. 5). Vascular wall infiltration was seen in $80 \%$ of cases (four of five) and pleural and bronchial wall infiltration was noted in three of five (60\%) cases (Fig. 6). Amyloid was present within the consolidated pulmonary parenchyma and walls of vessels and airways, and was associated with a non-necrotizing granulomatous component in $80 \%$ (four of five) of cases.

The primary pulmonary lymphomas showed two distinct cytomorphologies: three cases had cytologic features of a mucosa-associated lymphoid tissue type (MALT) lymphoma and two cases showed features of B-cell chronic lymphocytic leukemia/ small lymphocytic lymphoma (Fig. 7). In the former, the lymphoid infiltrate consisted of an admixture of small round lymphocytes, monocytoid lymphocytes, plasma cells, and centrocyte-like (marginal zone) cells. In the small lymphocytic lym- 


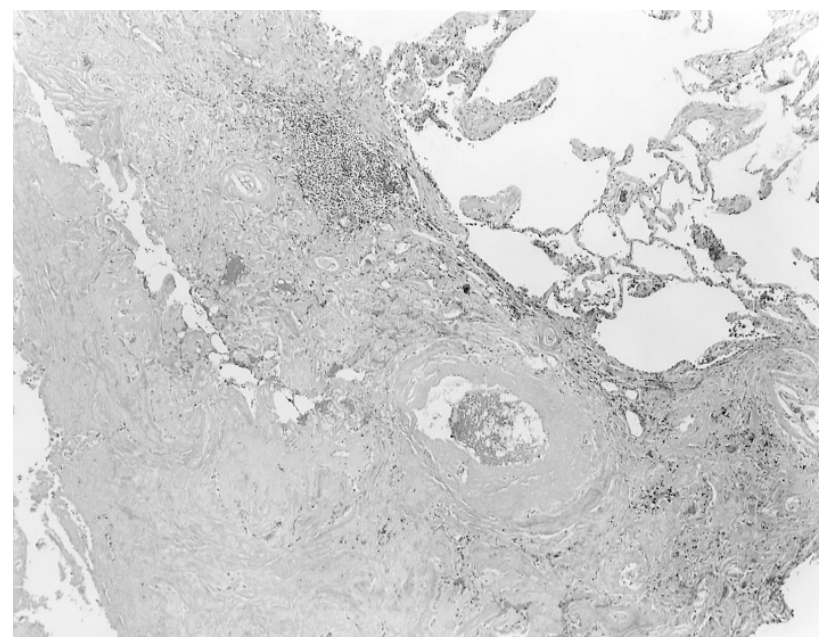

FIGURE 1. Amyloidoma: Sharply demarcated dense amyloid deposits in the lung parenchyma and blood vessels were associated with a scant lymphoplasmacytic infiltrate that was more prominent at the periphery of the nodule than in its center (hematoxylin and eosin stain, original magnification, $16 \times)$.

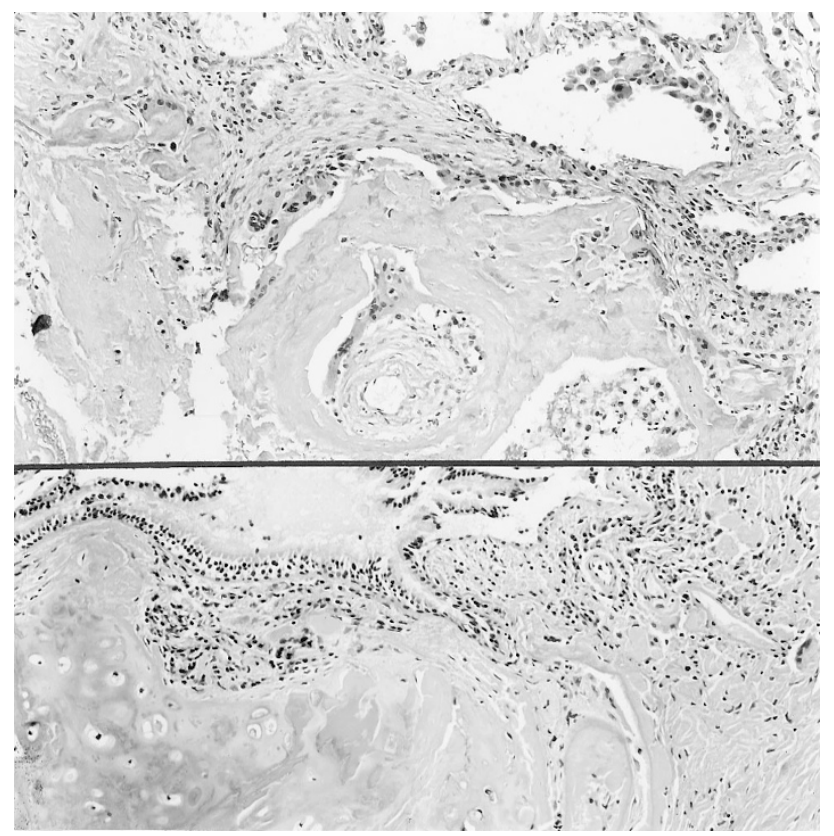

FIGURE 2. Amyloidoma: Amyloid deposits were seen within the walls of blood vessels, accompanied by a granulomatous reaction (top), as well as within the walls of airways (bottom) where it was associated with osteocartilaginous metaplasia (hematoxylin and eosin stain, original magnification, $40 \times$ ).

phomas, the infiltrate largely consisted of small round lymphocytes, plasmacytoid lymphocytes, and plasma cells. In both lymphoma subtypes, sheets of plasma cells were recognized. No Dutcher bodies were seen in any case, although Russell bodies were seen in two cases. In $80 \%$ of cases, reactive germinal centers with marginal zone expansion were identified. Lymphoepithelial lesions were identified in only one case.

Table 3 shows the immunohistochemical results of the study of the lymphomas. In nodular amyloi-

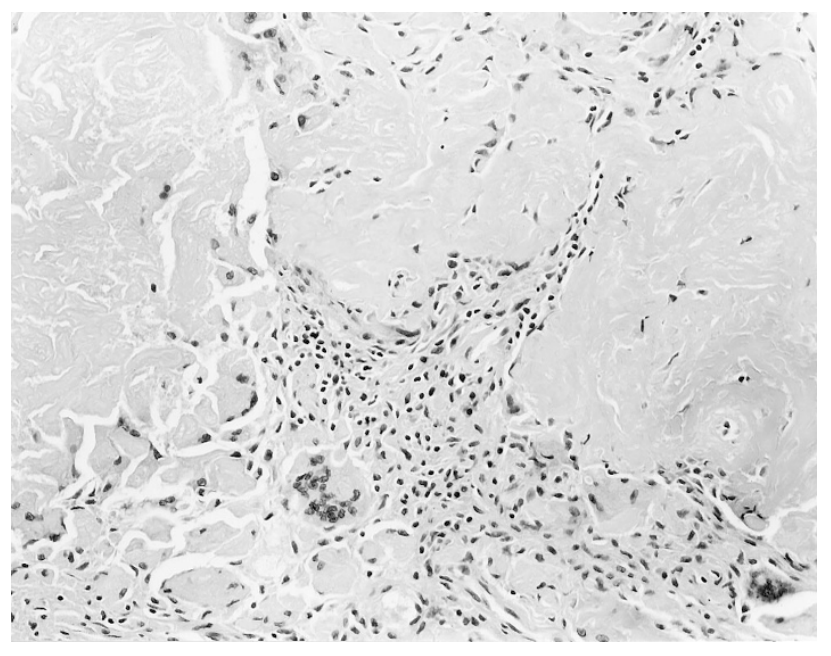

FIGURE 3. Amyloidoma: A foreign body giant cell reaction is seen associated with amyloid deposits and scant numbers of lymphocytes and histiocytes (hematoxylin and eosin stain, original magnification, $40 \times)$.

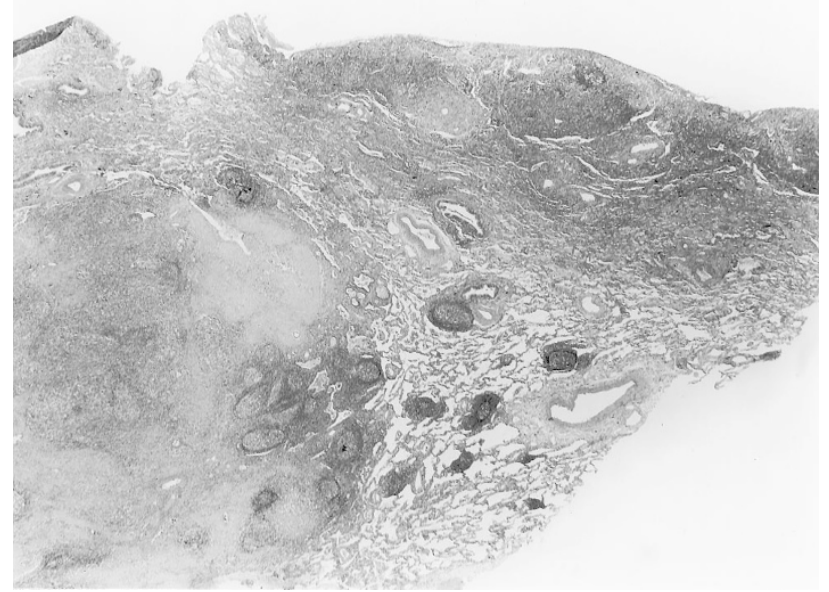

FIGURE 4. Malignant lymphoma: Lymphomas with amyloid formed ill-defined nodules associated with lymphatic tracking and pleural infiltration. The mononuclear infiltrate was usually striking in its intensity and was associated with reactive lymphoid follicles in a majority of cases (hematoxylin and eosin stain, original magnification, $8 \times)$.

doma, the lymphocytic infiltrate contained a predominant population of $\mathrm{T}$ cells, which stained strongly for CD3 and CD5 with a minor subset of CD20 + B cells. No coexpression of CD20 and CD43 by lymphocytes was identified. CD21 stains highlighted an interconnecting meshwork of follicular dendritic cell processes in $60 \%$ of cases associated with CD10 positive follicular B cells. CD138, a plasma cell marker, showed aggregates of plasma cells in $33 \%$ of cases. No sheet-like distributions of plasma cells (more than 20 cells) were identified. Immunostains for kappa and lambda light chain failed to show evidence of a clonal population.

The primary pulmonary lymphomas contained a dominant B-cell population, demonstrated best with antibodies to CD79a, and associated with a 


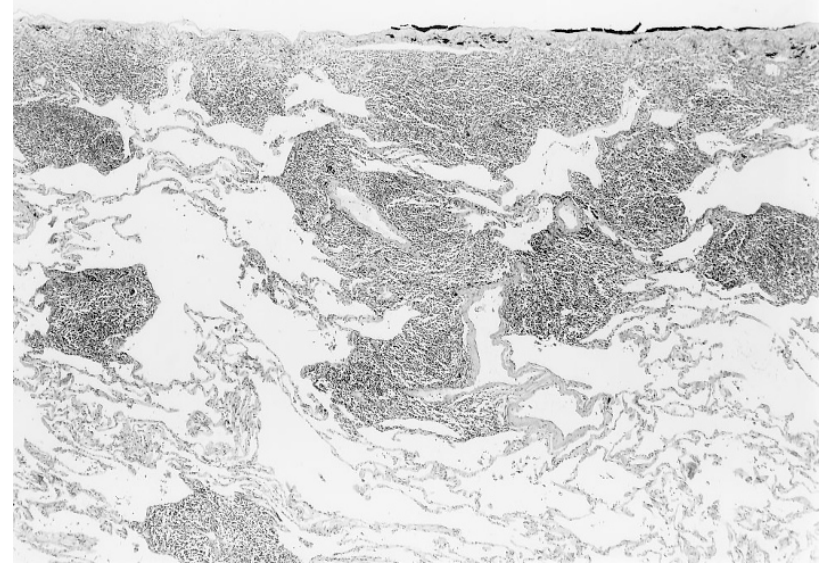

FIGURE 5. Malignant lymphoma: Lymphatic tracking and pleural infiltration by neoplastic lymphocytes was often seen (hematoxylin and eosin stain, original magnification, $16 \times$ ).

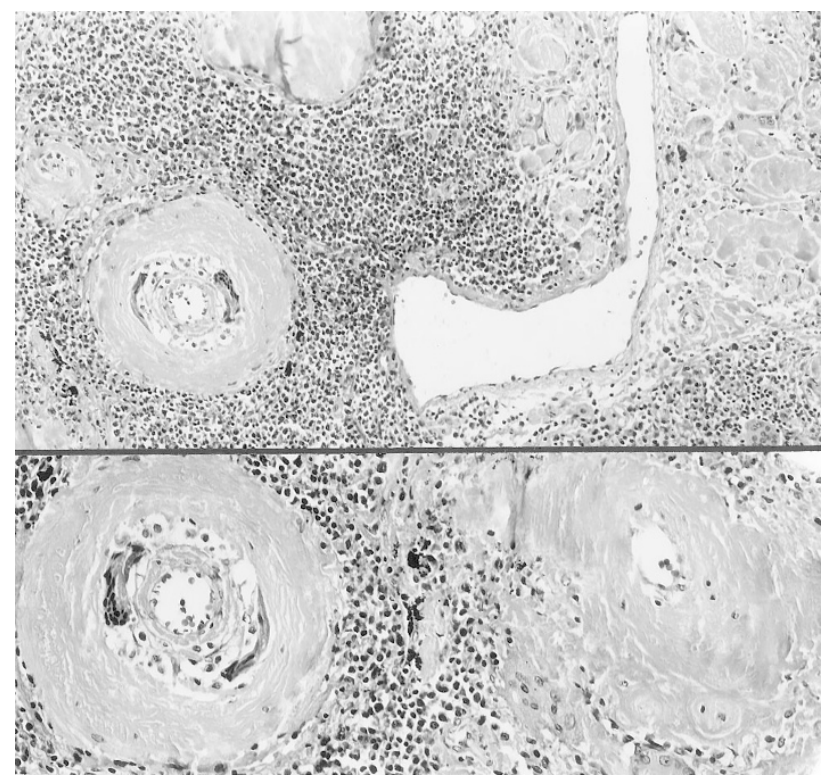

FIGURE 6. Malignant lymphoma: Vascular wall deposits of amyloid were accompanied by a granulomatous reaction. The lymphoid infiltrate in lymphomas was intense and lacked a gradient from the center of the nodular lesions to their periphery (hematoxylin and eosin stain, original magnification, $40 \times$, top; $80 \times$, bottom).

minor CD3 positive T-cell infiltrate. In the two cases classified as B-cell CLL/SLL and MALT lymphoma, coexpression of CD20 and CD43 was seen in the neoplastic lymphocytes. Follicular dendritic cells were identified with CD21 immunostaining in $60 \%$ of cases, and these areas were associated with focal expression of CD10 by follicular center type B cells. CD138 showed broad zones of positive cells consisting largely of plasmacytoid lymphocytes and mature plasma cells. Neoplastic lymphocytes and plasma cells in two cases showed restricted IgM kappa expression, and in two cases showed IgG lambda expression. One case failed to show lightchain restriction.

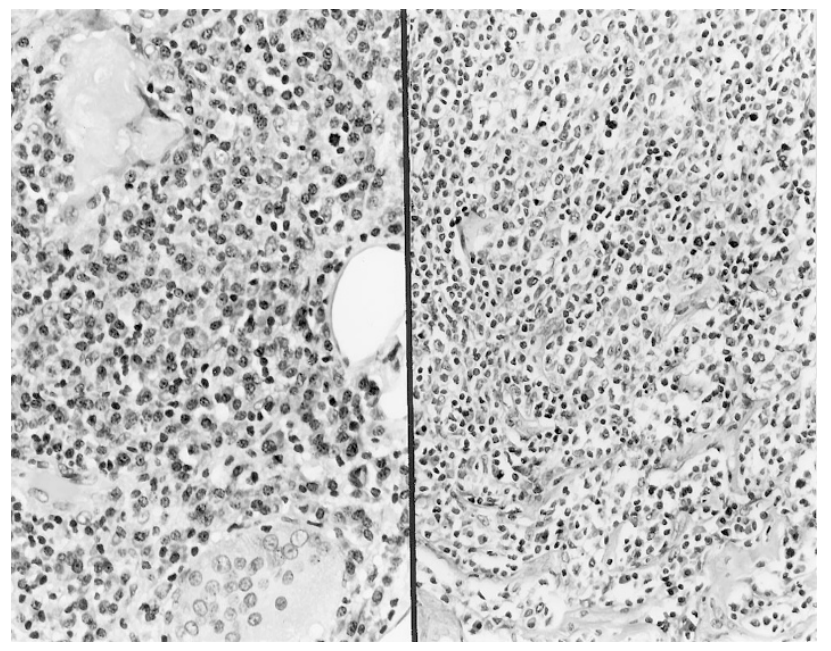

FIGURE 7. Malignant lymphoma: B-cell CLL/SLL consisted of sheets of small round lymphocytes, plasmacytoid lymphocytes, and plasma cells (right), whereas a mixture of small round and plasmacytoid lymphocytes with monocytoid cells and transformed large lymphocytes characterized mucosa-associated low grade B-cell lymphoma (left) (hematoxylin and eosin stain, original magnification, $160 \times$, left; $80 \times$, right).

Cyclin D1 immunostains were performed on these cases but were very difficult to interpret because of the unusually high background related to amyloid deposits and serum leakage.

\section{DISCUSSION}

Lymphoproliferative diseases affecting the lung occur over a broad clinical and pathologic spectrum. Most primary pulmonary lymphomas derive from the bronchus-associated lymphoid tissue (BALT) and have a B-cell phenotype $(14,15)$. These lymphomas may contain amyloid deposits, but this finding is extremely rare, occurring in less than $1 \%$ of cases. Amyloid more often deposits in the lung independent of lymphoplasmacytic neoplasms, usually in the form of nodular pulmonary amyloidosis with bilateral multiple nodules occurring in an elderly individual (Table 4). In some instances, such nodules may relate to preexisting chronic inflammatory conditions or may be associated with autoimmune conditions such as Sjögren's syndrome. The histologic overlap between nodular amyloidoma and malignant lymphomas associated with amyloid raises questions about distinctive histologic and immunohistochemical characteristics, which can be used to separate the two.

In this study, we analyzed clinicopathologic, histologic, and immunohistochemical features of six cases of nodular amyloidosis and five cases of low grade B-cell lymphomas associated with amyloid deposits. Several histologic features allowed some discrimination between the two entities. First, patients with low-grade lymphoma tended to demonstrate lymphatic tracking at the edge of the amyloid 
TABLE 3. Immunophenotypic Findings in Primary Pulmonary Lymphomas with Amyloid

\begin{tabular}{clllllllllllllll}
\hline Lymphoma & REAL Classification & Working Formulation & CD5 & $\begin{array}{c}\text { CD20/CD43 } \\
\text { Coexpression }\end{array}$ & CD23 & CD20 & CD79a & CD138 & $\kappa$ & SIg & CD10 & & & &
\end{tabular}

B-cell CLL/SLL, B-cell chronic lymphocytic leukemia/small lymphocytic lymphoma; MALToma, low-grade B-cell lymphoma derived from mucosa associated lymphoid tissue; SIg, surface immunoglobulin.

mass, and tended to have intense lymphoid infiltrates that did not show a significant intensity gradient from the center of the mass to its periphery. Vascular and bronchial wall infiltration, although suggestive of lymphoma, was seen in cases of nodular amyloidoma $(16,17)$. Pleural infiltration, however, was exclusively limited to the lymphomas (18, 19). Whereas the amyloidomas contained scattered plasma cells and small round lymphocytes, the lymphomas tended to have either a monotonous population of small round lymphocytes with plasma cell differentiation or the characteristic heterogeneity of MALT type lymphomas with small round lymphocytes, centrocyte-like cells, monocytoid lymphocytes, and plasma cells. In the lymphomas, there was often seen a sheet-like distribution of uniform plasmacytic elements forming broad sheets (greater than 20 cells in aggregate), in contrast of the cases of nodular amyloid. Germinal centers were more often associated with lymphomas than with nodular amyloidoma. The presence of non-necrotizing granulomatous inflammation was not helpful distinguishing feature.

The immunohistochemical analysis of these 11 cases revealed several interesting features. First, the immunophenotypic identification of a B-cell lymphoma is relatively straightforward if the composition of the neoplasm is monomorphic. However, if the cellular composition is heterogeneous and includes many reactive cells, immunophenotyping can be more difficult. One of the classic antigens used to detect B-cell lineage with great specificity and sensitivity is CD20 (20). In our study, we found the detection of B cells by CD20 to be surpassed by CD79. This is consistent with previous studies showing that the major advantage of CD79 over CD20 is reactivity with normal and neoplastic B cells at all stages of differentiation from early B cells to plasma cells (21). The identification of the B-cell

TABLE 4. Causes of Amyloid Deposits in the Lung

1. Idiopathic

2. Chronic inflammatory disorders (e.g., infection, aspiration)

3. Connective tissue diseases

4. Lymphoproliferative diseases

(a) Multiple myeloma

(b) Lymphoplasmacytic type lymphoma

(c) Systemic light chain disease infiltrate was helpful in alerting the diagnostic pathologist of the potential for amyloid deposits to be due to a coexistent malignant lymphoma because B cells dominated in the lymphoma cases and were overwhelmed by the T-cell component in nonneoplastic amyloidomas. Second, the CD138 antibody is extremely helpful in accentuating the plasma cell component in lymphomas and nodular amyloidoma. CD138 highlights the sheet-like distribution of plasma cells in the malignant lymphoproliferative disorders, a finding that is inconspicuous in cases of nodular amyloid and appears to be very specific for low grade B-cell lymphomas of the lung (22). Third, the use of both CD43 and CD20 was helpful in two cases in which the pattern of immunostaining reflected aberrant coexpression of these two antigens and provided further support for the diagnosis of malignant lymphoma $(23,24)$.

In addition to excluding malignant lymphoma, nodular amyloidosis needs to be discriminated from pulmonary hyalinizing granuloma (Table 5) (25). Clinically, there is great overlap between these two entities, although patients with hyalinizing granuloma tend to have a history of exposure to histoplasma or tuberculous antigens. The chest $\mathrm{x}$-rays in both conditions may show solitary or multiple pulmonary nodules. Histologically, hyalinizing granulomas are composed of thick, acellular, whorl-like deposits of lamellar collagen that are Congo-red negative. This material needs to be discriminated from the waxy, amorphous eosinophilic material that is characteristic of amyloid and stains Congo-red positive.

It is worthwhile to highlight some of the technical difficulties experienced during our study of these cases. First, in our hands, antibody evaluation of the different types of amyloid was very difficult to interpret and often associated with a high background. This precluded assessment of whether the

TABLE 5. Differential Diagnosis of Nodular Amyloidosis and Lymphomas with Amyloid Deposits

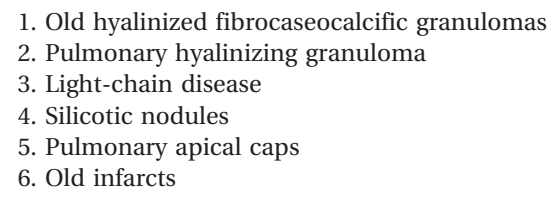

1. Old hyalinized fibrocaseocalcific granulomas

2. Pulmonary hyalinizing granuloma

3. Light-chain disease

4. Silicotic nodules

5. Pulmonary apical caps

6. Old infarcts 
amyloid was related to plasma cell dyscrasias, inherited disease, or chronic inflammation. Second, the involvement of blood vessels by amyloid resulted in high background for our immunostains, possibly as a result of excessive leakiness. For some antibodies, interpretation was extremely difficult, including the identification of Cyclin D1.

\section{Acknowledgment: The authors appreciate the secre-} tarial assistance of Diana Winters.

\section{REFERENCES}

1. Cordier JF, Loire R, Brune J. Amyloidosis of the lower respiratory tract. Clinical and pathologic features in a series of 21 patients. Chest 1986;90:827-30.

2. Utz JP, Swensen SJ, Gertz MA. Pulmonary amyloidosis. The Mayo Clinic experience from 1980 to 1993. Ann Intern Med 1996;124:407-13.

3. da Costa P, Corrin B. Amyloidosis localized to the lower respiratory tract: probable immunoamyloid nature of the tracheobronchial and nodular pulmonary forms. Histopathology 1985;9:703-10.

4. Hui AN, Koss MN, Hochholzer L, Wehunt WD. Amyloidosis presenting in the lower respiratory tract. Clinicopathologic, radiologic, immunohistochemical, and histochemical studies on 48 cases. Arch Pathol Lab Med 1986;110:212-8.

5. Kobayashi H, Matsuoka R, Kitamura S, Tsunoda N, Saito K. Sjogren's syndrome with multiple bullae and pulmonary nodular amyloidosis. Chest 1988;94:438-40.

6. Stokes MB, Jagirdar J, Burchstin O, Kornacki S, Kumar A, Gallo G. Nodular pulmonary immunoglobulin light chain deposits with coexistent amyloid and nonamyloid features in an HIV-infected patient. Mod Pathol 1997;10:1059-65.

7. Podbielski FJ, Nelson DG, Pearsall GF, Marquez GD, Connolly MM. Nodular pulmonary amyloidosis. J Thorac Cardiovasc Surg 1997;114:289-91.

8. Davis CJ, Butchart EG, Gibbs AR. Nodular pulmonary amyloidosis occurring in association with pulmonary lymphoma. Thorax 1991;46:217-8.

9. Kim H, Heller P, Rappaport H. Monoclonal gammopathies associated with lymphoproliferative disorders: a morphologic study. Am J Clin Pathol 1973;59:282-94.

10. Miura K, Shirasawa H. Lambda III subgroup immunoglobulin light chains are precursor proteins of nodular pulmonary amyloidosis. Am J Clin Pathol 1993;100:561-6.

11. Schiffer M. Molecular anatomy and the pathological expression of antibody light chains. Am J Pathol 1996;148:1339-44.

12. Quintana PG, Kapadia SB, Bahler DW, Johnson JT, Swerdlow SH. Salivary gland lymphoid infiltrates associated with lymphoepithelial lesions: a clinicopathologic, immunophenotypic, and genotypic study. Hum Pathol 1997;28:850-61.

13. Harris NL, Jaffe ES, Stein H, Banks PM, Chan JKC, Cleary ML, et al. A revised European-American classification of lymphoid neoplasms: a proposal form from the International Lymphoma Study Group. Blood 1994;84:1361-92.

14. Li G, Hansmann M-L, Zwingers T, Lennert K. Primary lymphomas of the lung: morphological, immunohistochemical and clinical features. Histopathology 1990;16:519-31.

15. Herbert A, Wright DH, Isaacson PG, Smith JL. Primary malignant lymphoma of the lung: histopathologic and immunologic evaluation of nine cases. Hum Pathol 1984;15:41522.

16. Doran HM, Sheppard MN, Collins PW, Jones L, Newland AC, Van der Walt JD. Pathology of the lung in leukaemia and lymphoma: a study of 87 autopsies. Histopathology 1991;18: 211-9.

17. Colby TV, Carrington CB. Pulmonary lymphomas: current concepts. Hum Pathol 1983;14:884-7.

18. Koss MN, Hochholzer L, Nichols PW, Wehunt WD, Lazarus AA. Primary non-Hodgkin's lymphoma and pseudolymphoma of lung: a study of 161 patients. Hum Pathol 1983; 14:1024-38.

19. Turner RR, Colby TV, Doggett RS. Well-differentiated lymphocytic lymphoma. A study of 47 patients with primary manifestation in the lung. Cancer 1984;54:2088-96.

20. Mason DY, Comans-Bitter WM, Cordell JL, Verhoeven AJ, van Dongen JJM. Antibody L26 recognizes an intracellular epitope on the B-cell-associated CD20 antigen. Am J Pathol 1990;136:1215-22.

21. Mason DY, Cordell JL, Brown MH, Borst J, Jones M, Pulford $\mathrm{K}$, et al. CD79a: a novel marker for B-cell neoplasms in routinely processed tissue samples. Blood 1995;86:1453-9.

22. Wijdenes J, Vooijs WC, Clement C, Post J, Morard F, Vita N, et al. A plasmocyte selective monoclonal antibody (B-B4) recognizes syndecan-1. Brit J Haematol 1996;94:318-23.

23. Treasure J, Lane A, Jones DB, Wright DH. CD43 expression in B cell lymphoma. J Clin Pathol 1992;45:1018-22.

24. Contos MJ, Kornstein MJ, Innes DJ, Ben-Ezra J. The utility of CD20 and CD43 in subclassification of low-grade B-cell lymphoma on paraffin sections. Mod Pathol 1992;5:631-3.

25. Yousem SA, Hochholzer L. Pulmonary hyalinizing granuloma. Am J Clin Pathol 1987;87:1-6. 